\title{
Lesión tumoral de aspecto polipoide
}

\author{
Molinero Barranco MA. ${ }^{1}$
}

Sanid. mil. 2011; 67 (4): 381-382; ISSN: 1887-8571

Paciente de sexo femenino, natural de la provincia de Sevilla, de 36 años de edad, casada, un hijo y administrativa de profesión. Entre los antecedentes patológicos personales cabe destacar la realización de una cesárea en el único parto que ha tenido. Los antecedentes familiares carecen de interés. Refiere que le aparece en el segundo dedo de la mano derecha una lesión rojiza, de aspecto verrugoso que sangra con facilidad y que crece en pocas semanas hasta adquirir las características actuales. No realiza ningún tratamiento.

A la exploración se observa una lesión verrugosa, polipoide, discretamente pediculada, con un collarete epidérmico, de color ro- jizo y superficie recubierta por una pseudomembrana blanquecina, del tamaño de un guisante y se ubica en lado interno de la tercera falange del segundo dedo de la mano derecha, cerca del borde periungueal. Biopsiamos la lesión y el estudio histopatológico nos informa que se observa una lesión recubierta por un endotelio adelgazado conformado por lóbulos de vasos capilares rodeados por un infiltrado inflamatorio compuesto por gran cantidad de neutrófilos. Por debajo del epitelio existe una gran proliferación de vasos capilares de pared fina, dispuestos en islotes o lóbulos rodeados de tejido conjuntivo laxo y edematoso.

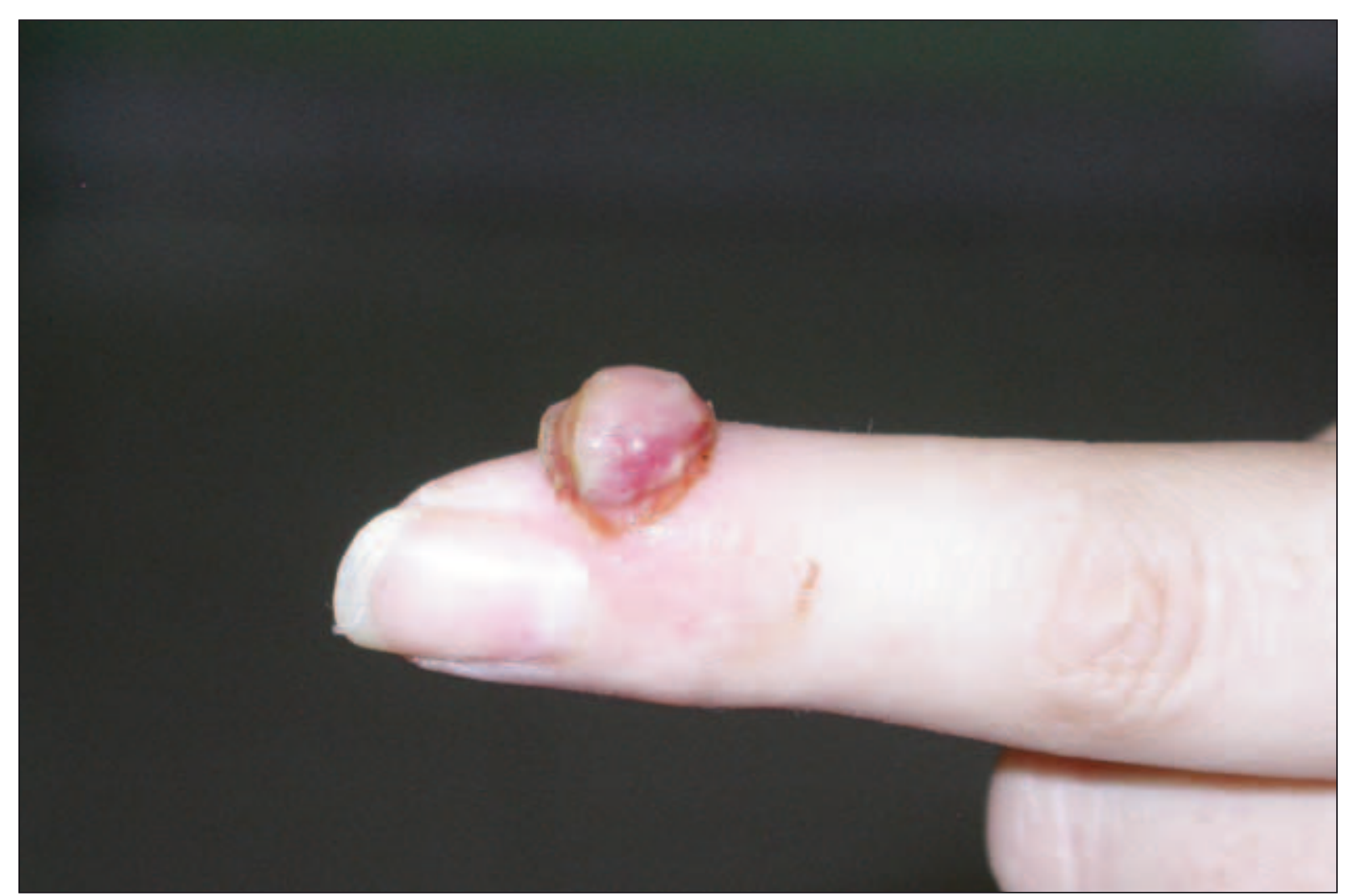

Figura 1. Lesión polipoide en el dedo.

${ }^{1}$ Tcol. Médico (Retirado).

Dirección para correspondencia: mamolba@telefonica.net

Recibido: 8 de noviembre de 2010

Aceptado: 13 de enero de 2011 


\section{Diagnóstico: Granuloma telangiectásico o botriomicoma}

\section{DISCUSIÓN}

El botriomicoma o granuloma telangiectásico es un proceso hiperplásico que se corresponde con una producción excesiva de tejido de granulación. Otros consideran que se trata de una neoplasia vascular por el patrón histopatológico globular similar al que se observa en éstas ${ }^{1}$. Hay autores que los consideran una piodermitis vegetante ${ }^{2}$.

La clínica es característica, resaltando el aspecto polipoide y el color rojizo, así como el collarete epidérmico que suelen presentar en la base. Otra característica clínica es el sangrando tras el mínimo traumatismo, así como su ubicación típica en los dedos, en los labios, lengua y región escapular.

Pero quizá lo más importante sea el diagnóstico diferencial con otras lesiones, algunas de ellas de fatal evolución, como el melanoma nodular amelanótico ${ }^{3,4}$ Otras lesiones que debemos tener presente son el carcinoma basocelular, el carcinoma espinocelular, metástasis cutáneas de carcinomas endógenos, hemangiomas, tumor glómico, nevo de Split, xantogranuloma juvenil, verruga vulgar, molusco contagioso y la angiomatosis bacilar ${ }^{4,5}$, de lo que se desprende que el estudio histopatológico es fundamental para alcanzar el diagnóstico.
El tratamiento consiste en el curetaje y electrocoagulación. Esta es la técnica que empleada en este caso, con excelentes resultados.

$\mathrm{Si}$ las proliferaciones vasculares alcanzaran la dermis reticular, las recidivas serían frecuentes, por lo que habría que recurrir a la extirpación quirúrgica que incluyera piel no afectada en los márgenes laterales y profundos ${ }^{1}$

\section{BIBLIOGRAFÍA}

1. Requena L., Requena C., Pichardo R.A., Sangueza O.P.: Granuloma piógeno. Monografías de Dermatología. 2004; 17: 43-51.

2. Camacho F.: Dermatosis bacterianas: piodermitis. Otras dermatosis bacterianas. En: ARMIJO M., Camacho F.: Tratado de Dermatología II. Ed Aula Médica S.A. Madrid 1998; 757.

3. Bielsa Marsol I.: Tumores mesenquimales En: FERRÁNDIZ C.: Dermatología Clínica. Ed Elsevier. Barcelona 2009; 372.

4. Weston WL., Lane AT., Morelli JG.: Dermatología pediátrica. Texto y Atlas en color. Elsevier España S.A. Masson. Barcelona 2008; 250-252.

5. Pastor Pascual F., Aviño Martínez J., España Gregori E., Alcocer Yuste: Granulomas piógenos en tapones lagrimales smart plug. Arch Soc Esp Oftalmol v.82 $\mathrm{n}^{\circ} 10$. Madrid 2007 